\title{
Study of geotechnical aspect base on GIS as basic design of road
}

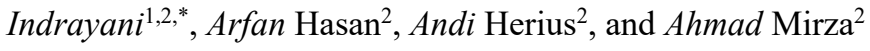 \\ ${ }^{1}$ Doctoral Student of Environmental Science of Sriwijaya University, Palembang, Indonesia \\ ${ }^{2}$ Civil Engineering Department, State Polytechnic of Sriwijaya, Palembang, Indonesia
}

\begin{abstract}
The determination road traces are the first step in road planning. Geotechnical aspects such as soil type, soil texture, peat soil, and CBR value should be considered during road planning so as to obtain the age of road services in accordance with the plan. At this time, GIS can be used in identifying the physical environmental conditions in the determination of road traces to increase time and cost efficiency. The suitability of the geotechnical aspects is determined using the scoring and weighting method. Each attribute is assigned a value with a range of values between 1 and 5. A score of 1 is given for the most suitable parameter, while a score of 5 is given if very unsuitable. The weights ratio of each criterion is $25 \%$ because each aspect has the same level of importance. Spatial analysis of the weighting result is done by the overlay method to obtain the geotechnical aspect appropriateness in determining road traces. The analysis results show that the lowest weights on the result of the overlay of the map is 2.25 which indicates that most of the area in Banyuasin Regency is "quite suitable" to be chosen as road traces.
\end{abstract}

\section{Introduction}

The development of a region requires road infrastructure to facilitate accessibility. The determination of road traces is the first step in road planning [1] and at present, it can be done using GIS technology and Remote Sensing [2]. Sustainable development can be achieved if road traces take into account the existing environmental condition, since sustainable development will be difficult to achieve if development policies are not based on the potential of human resources, natural resources and artificial resources [3]. Physical environmental aspects have a major role in the achievement of sustainable development [4], which includes geotechnical aspects, such as soil type, peat soil, soil texture, and CBR value. The type of soil strongly influences the construction [5]. Peatlands need to be considered because the study area is a swamp area. Similarly, soil texture and CBR values are considered, since both affect pavement performance to support vehicle loads on it [6] [7]. Classification of soil texture is based on AASHTO used by The Directorate General of Highways on road construction in Indonesia. This study aims to spatially analyze geotechnical aspects in determining road traces.

\footnotetext{
*Corresponding author : iiend.indrayani@gmail.com
} 


\section{Methodology}

\subsection{Framework analysis}

The method used in this research is the overlay method on geotechnical aspect weights, including soil type, soil texture, CBR value, and peat depth. The data used are secondary data obtained from related institutions, such as soil type maps and peat depth maps, whereas soil texture and CBR values were determined based on soil type conversion literature and results of previous studies [8] [9]. Each attribute is assigned a value with a range of values between 1 and 5. A score of 1 is given for the most suitable parameter, while a score of 5 is given if very unsuitable. The weights ratio of each criterion is $25 \%$ because each aspect has the same level of importance. From this research a thematic map of road traces conformation will be produced.

\subsection{Study area}

The study area in this study was Banyuasin District located at the coordinate point $1^{\circ} 37^{\prime} 32.12^{\prime \prime}$ up to $3^{\circ} 09^{\prime} 15.03^{\prime \prime} \mathrm{LS}$ and $104^{\circ} 02^{\prime} 21.79^{\prime \prime}$ up to $105^{\circ} 33^{\prime} 38.5^{\prime \prime} \mathrm{BT}$ [10], and can be seen in Fig.1.

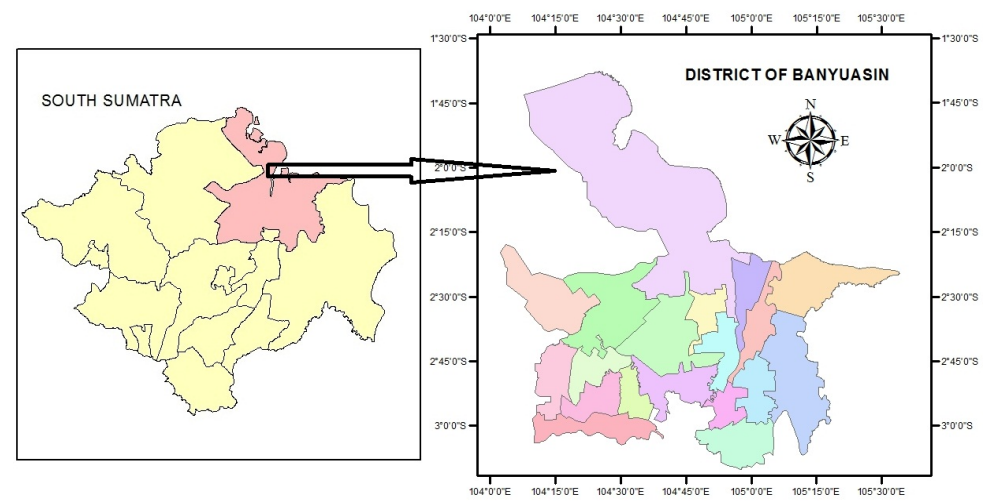

Fig. 1. Study area.

\section{Data and analysis}

\subsection{Data}

Soil characteristics are very important to be considered in the beginning step of road construction [5], so it is necessary to classify the soil based on soil properties [2]. In the study area, the soil type was classified into 5, i.e. (i) alluvial, gley, planosolm, hydromorphic is insensitive and has a score of 1; (ii) laterit, latosol is moderately sensitive and has a score of 2; (iii) brown soil is less sensitive and has a score of 3; (iv) andosol, laterit, grumosol, podsol, and podsolik is sensitive and has a score of 4; (v) regosol, litosol, organosol, and renzina is very sensitive and has a score of 5 [11] [12].

Generally, the swamp area consists of peat soil, where the peat depth is divided into 5 classes, i.e. : (i) 20 - 50 is not too shallow having a score of 1; (ii) $50-100$ is shallow/thin with a score of 2; (iii) $100-200$ is moderate with a score of 3; (iv) $200-400$ is deep/thick and has a score of $4 ;(v)>400$ is very deep/thick and has a score of 5 [13]. 
In road planning, the rules used in the classification of soil base on the AASHTO system, where AASHTO classifies the soil into 7 groups, namely: A1 is gravel and stone; A2 is a gravel with silt, gravel with sand, and gravel with clay; A3 is fine sand; A4, A5, and A6 are silt, and A7 is clay [14]. Soil texture is taken by an approach of soil type, i.e.: alluvial soil has a clay or sandy clay texture; entisol soil has a coarse sandy texture; glei soil, latosol and hydromorf have a clay texture; whereas lithosol and regosol soil have a sandy texture [15]. Scoring of the soil texture is based on the texture. The rougher the texture of the soil, the better as the road alignment, scoring is done as follows: 1 for gravel, 2 for fine sand, 3 for sand with silt and sand with clay, 4 for silt, and score 5 for clay [14].

CBR values was taken based on previous research results and approach to soil texture. Soil with highest CBR value is the best to take as road traces. Scoring of CBR value is done as follows: score 1 for CBR > 50\%; score 2 for CBR $20-50 \%$; score 3 for CBR $7-20 \%$; score 4 for CBR 3 - 7\% and score 5 for CBR 0 - 3\% [16]. Criteria for the geotechnical aspects can be seen in Fig. 2.

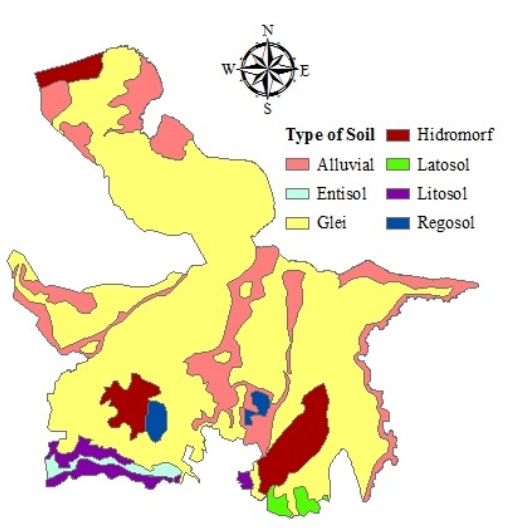

a. The map of soil type

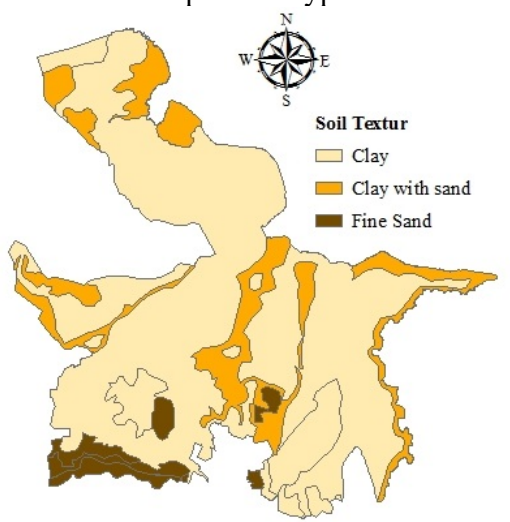

c. The map of soil texture

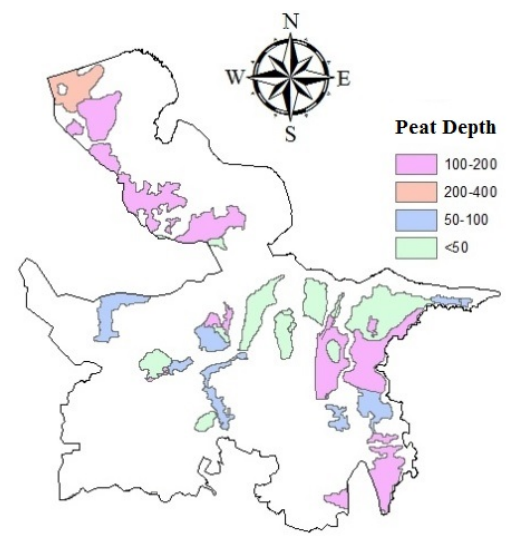

b. The map of peat depth

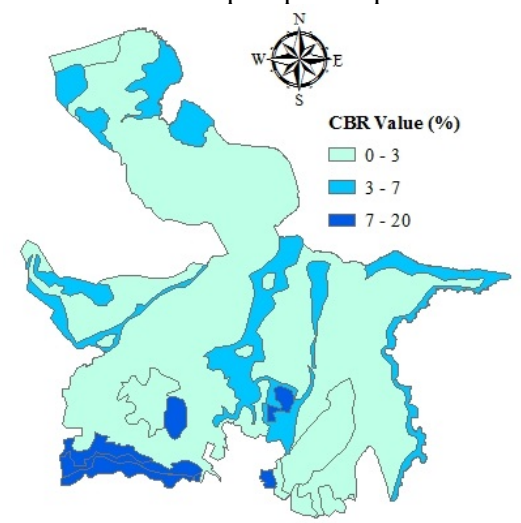

d. The map of CBR Value

Fig. 2. Criteria of the geotechnical aspects.

Each of the geotechnical aspects are considered to have the same level of importance and are given weights of $25 \%$. The score of each criterion is multiplied by the weights of each aspect of $25 \%$. 


\subsection{Analysis}

The analysis is done by overlay method, that is by unifying all maps of geotechnical aspects that have been given weight so as to obtain the suitability of the geotechnical aspects in the determination of the road traces. The equation used in overlaying between scores and weights is:

$$
X=\sum_{i=1}^{n}(W i x X i)
$$

Where: $\mathrm{X}$ is the conformity value of the geotechnical aspect; Wi is the weights parameter for- $\mathrm{i}$; $\mathrm{Xi}$ is the value for- $\mathrm{i}$ parameter.

From the equation above we obtain the weights on the map of geotechnical aspect conformity as shown in Table 1.

Table 1. Weights of geotechnical aspects suitability.

\begin{tabular}{|c|c|c|}
\hline Rank & Geotechnical Aspects Suitable & Weights \\
\hline 1 & Very Suitable & $<0.88$ \\
\hline 2 & Suitable & $0.88-1.60$ \\
\hline 3 & Quite Suitable & $1.60-2.40$ \\
\hline 4 & Unsuitable & $2.40-3.20$ \\
\hline 5 & Very Unsuitable & $>3.20$ \\
\hline
\end{tabular}

\section{Result and discussion}

\subsection{Result}

The result of score-weights multiplication on each criterion of soil type, peat depth, soil texture, and CBR value can be seen in Fig. 3.

Fig. 3a shows that the lowest weights of soil type happen on gley and alluvial soil. This indicates that this area can be selected as a road traces because the soil has low sensitivity to erosion. The peat depth map (Fig. 3b) shows that the lowest weights are located at 20 to $50 \mathrm{~cm}$ depth. This means that this area can also be selected as a road traces, however, it still needs special treatment. While the lowest weights on soil texture map (Fig. 3c) are found on fine sandy texture. Therefore, it is the most suitable road traces because the coarser the grains, the higher the carrying capacity. This is related to the CBR map (Fig. 3d) which also shows the lowest weights on the fine sandy soil.

Furthermore, these four maps will be overlaid to obtain the suitability of geotechnical aspects. The geotechnical aspects suitability map can be seen in Fig. 4. 


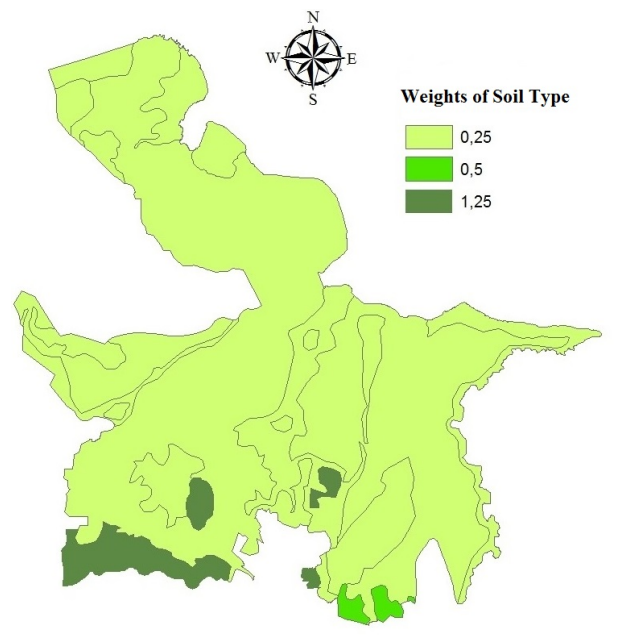

a. The weights of soil type

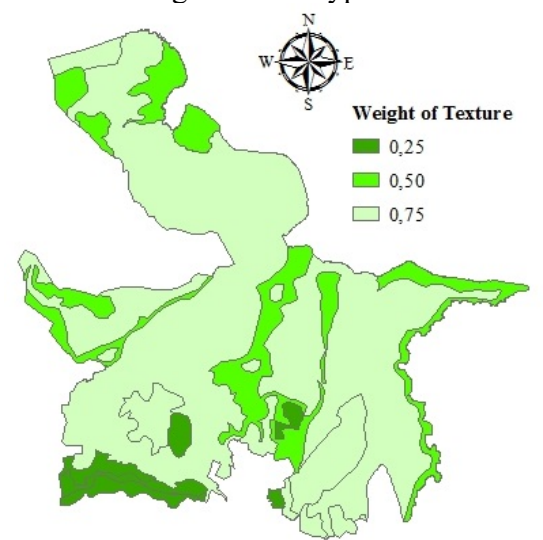

c. The weights of soil texture

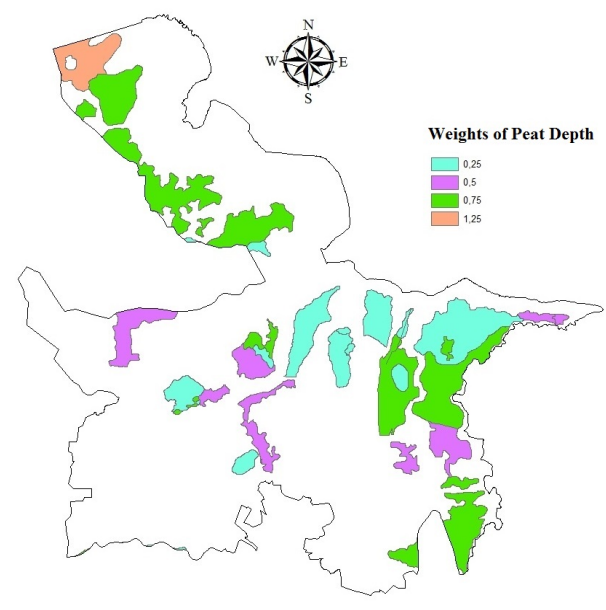

b. The weights of peat depth

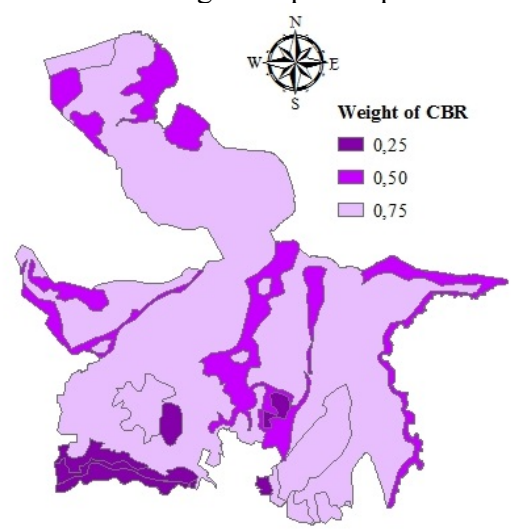

d. The weights of CBR

Fig. 3. The result of a score - weights multiplication on each criterion.

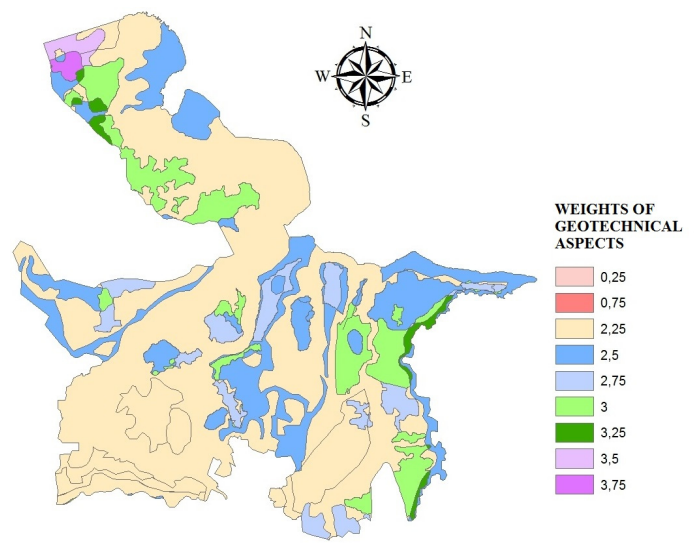

Fig. 4. Suitability map of geotechnical aspects. 
From the overlay result, it can be seen that the lowest weights are 2.25. This indicates that Banyuasin regency area is quite suitable for road traces, while some areas with weighting $>2.4$ are unsuitable to be taken as road traces.

\subsection{Discussion}

Banyuasin consists mostly of the swamp areas that have a low soil bearing capacity. From the results of the study, it can be seen that the average values of CBR in this area range from $<5 \%$ to $10 \%$, with a texture of clay to sandy clay, and some areas are peat soils with a depth of 50 to $200 \mathrm{~cm}$.

Banyuasin has enormous potential for development in various sectors such as agriculture, plantation, and industry. Such development requires road infrastructure. In this study, the level of conformity in the determination of road traces will not be the same as the construction in highland areas that have a high soil bearing capacity, due to the study area being a swamp area and having low soil bearing capacity, so there is no area which is really appropriate to be taken in the selection of road traces. Therefore, the construction of roads implemented in this area must be preceded by special calculations.

\section{Conclusion}

The results of this study show that the lowest weights on the result of the overlay of the map are 2.25 which indicates that most of the area in Banyuasin Regency is "quite suitable" to be chosen as the road traces, so special handling is needed for the road construction in this area.

Acknowledgments for State Polytechnic of Sriwijaya.

\section{References}

1. M. Dragan, P. Jarre, A Spatial MCA Process to Optimize Pipeline Alignment Choiches, HS+E Magazine, pp 34-39 (2015)

2. T. Subramani, and S.K. Nanda, National Highway Alignment Using GIS, International Journal of Engineering Research and Applications (IJERA), 2, Issue 4, July-August, pp $427-436$ (2012)

3. S. Hardjowigeno, Klasifikasi Tanah dan Pedogenesis, Akademika Pressindo, Jakarta (2003)

4. UNCED, Agenda 21, Rio Declaration, United Nation Commision Environmental Development Forest Principle, Rio De Janeiro (1992)

5. Suryanto, Daya Dukung Lingkungan Daerah Aliran Sungai Untuk Pengembangan Kawasan Permukiman SK: DAS Beringin Kota Semarang, Thesis, Master Degree Program of City and Regional Development Techniques, University of Diponegoro, Semarang (2007)

6. The Directorate General of Highways, Quantifying Impact Assessment Method Development for Road Management, Public Work Department, Jakarta (2006)

7. D.S. Gedafa, Present Pavement Maintenance Practice: A Case Study for Indian Condition Using HDM-4, Fall Student Conference Midwest Transportation Consortium, Ames, Iowa (2006)

8. E. Oktaviani, and R.P. Sari, Penyebab Kerusakan Jalan Tanjung Api-api Sta 16+105Sta 32+500, Final Report, Polytechnic of Sriwijaya, Palembang (2014) 
9. A.D. Prima, and P. Pangestu, Stabilisasi Tanah Lempung Menggunakan Limbah Cangkang Kerang ditinjau dari Nilai CBR, Final Report, Polytechnic of Sriwijaya, Palembang (2014)

10. RTRW Banyuasin, Spatial Plan District of Banyuasin 2011 - 2013, Government of Banyuasin District (2011)

11. Decree of the Minister of Agriculture No. 837/KPTS/UM/11/80, Criteria and Procedures for Determination of Protected Forest, (1980)

12. Decree of the Minister of Agriculture No. 683/KPTS/UM/8/81, Criteria and Procedures for Determination of Production Forest, (1981)

13. A. I. P. G. Widjaja, K. Nugroho, A. S. Didi, and A.S. Karama, Sumber Daya Lahan Rawa: Potensi, Keterbatasan, dan Pemanfaatan, National Meeting on Agricultural Development Land Swamp Tidal and Non Tidal Swamp, Maret, Cisarua (1992)

14. AASHTO, Standard Specification for Transportation Materials and Methods of Sampling and Testing, Part I: Specification. 19 $9^{\text {th }}$ edition, American Association of State Highway and Trasportation Officials, Washington D C (1998)

15. PPT, Classification of Soil in Indonesia, Land Research Centre, Bogor (1982)

16. M.B. Das, Mekanika Tanah, Part 1, Erlangga, Jakarta (1995). 